\title{
The Crystal Structure of 5,6-Epoxy-4-hydroxy-2-methoxy-
}

\section{-4,6-di-t-butylcyclohex-2-enone}

\author{
BENGT KARLSSON, ANNE-MARIE PILOTTI and ANNE-CHARLOTTE WIEHAGER
}

Department of Structural Chemistry, Arrhenius Laboratory, University of Stockholm, S-104 05 Stockholm, Sweden

The crystal structure of 5,6-epoxy-4-hydroxy-2methoxy-4,6-di-t-butylcyclohex-2-enone,

$\mathrm{C}_{15} \mathrm{H}_{24} \mathrm{O}_{4}$, has been determined by single-crystal $\mathrm{X}$-ray diffraction techniques. The unit cell is triclinic, space group $P \overline{1}$, with dimensions $a=$ 12.833, $b=11.695, c=10.861 \AA, \alpha=104.49, \beta=$ 94.62, $\gamma=96.83^{\circ}$. There are four molecules in the unit cell. Data were collected on an computer-controlled Philips PW 1100 diffractometer. The structure was determined by direct methods and refined by full-matrix least.squares; the final value of the conventional $R$ index is 0.062 .

The title compound may be prepared by autooxidation of 4,6-di-t-butylguaiacol in alkaline solution. The two molecules in the asymmetric unit are joined together by two hydrogen bonds, one from the hydroxyl oxygen of each molecule to the epoxide oxygen of the other. With the atoms of one molecule designated by primer, the distances $\mathrm{O}^{\prime}(15) \cdots \mathrm{H}(\mathrm{O} 14)$ and $\mathrm{O}(15) \cdot \cdots \mathrm{H}\left(\mathrm{O}^{\prime} 14\right)$ are 1.83 and $1.97 \AA$, respectively, and the angles $\mathrm{O}(15) \cdots \mathrm{H}\left(\mathrm{O}^{\prime} 14\right)-\mathrm{O}^{\prime}(14)$ and $O^{\prime}(15) \cdots H(O 14)-O(14)$ are 171 and $167^{\circ}$, respectively. Since the hydroxyl group and the epoxide ring are found to be cis to each other,

Table 1. Starting phases obtained from the convergence map. The correct phases are those without parentheses.

\begin{tabular}{rrrll}
\hline$h$ & & & $\phi_{h}$ & $\left|E_{h}\right|$ \\
\hline 0 & 3 & 1 & 0 & 3.58 \\
7 & -4 & 6 & 0 & 3.55 \\
5 & 8 & -7 & 0 & 3.02 \\
3 & 7 & -7 & $0,(\pi)$ & 3.65 \\
3 & -12 & 5 & $0,(\pi)$ & 3.22 \\
4 & 7 & -8 & $0,(\pi)$ & 3.04 \\
6 & -9 & 5 & $0,(\pi)$ & 2.73 \\
9 & -8 & -4 & $(0), \pi$ & 2.46 \\
\hline
\end{tabular}

Acta Chem. Scand. B 29 (1975) No. 5
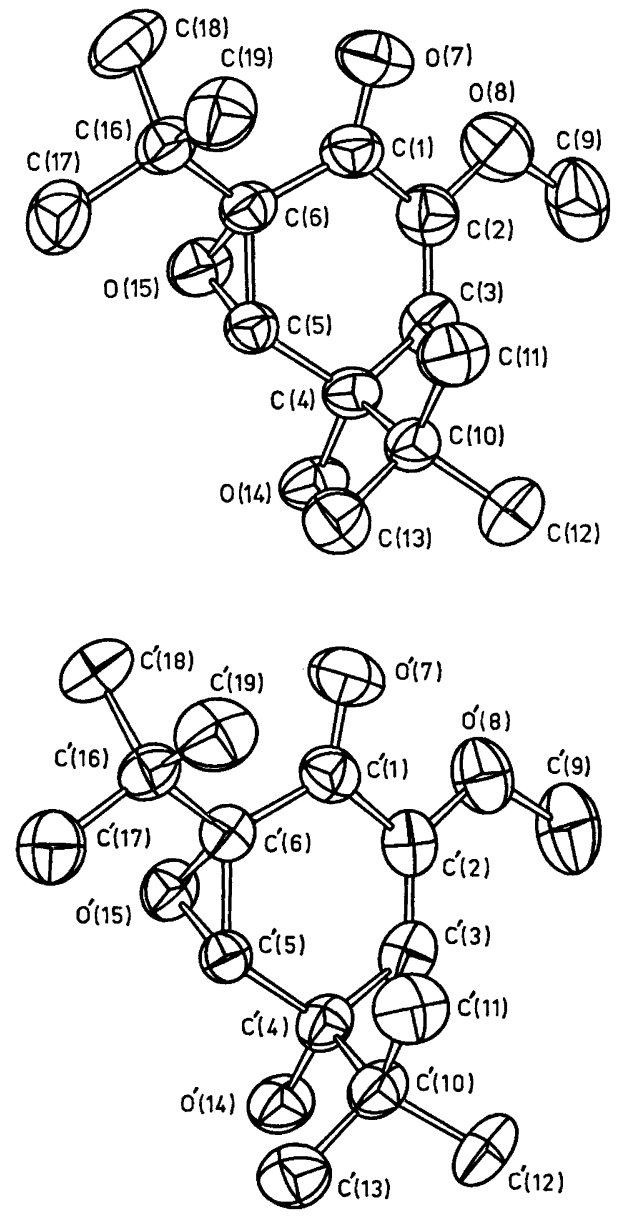

Fig. 1. Perspective views of the two separate molecules in the asymmetric unit. 
Table 2. Positional and anisotropic thermal parameters of the non-hydrogen atoms. The $\beta$-values refer to the temperature factor expression $\exp \left[-\left(h^{2} \beta_{11}+k^{2} \beta_{22}+l^{2} \beta_{33}+h k \beta_{12}+h l \beta_{13}+k l \beta_{23}\right)\right]$. Estimated standard deviations are given in parentheses. Values are $\times 10^{4}$.

\begin{tabular}{|c|c|c|c|c|c|c|c|c|c|}
\hline & $x$ & $y$ & $z$ & $\boldsymbol{\beta}_{11}$ & $\beta_{22}$ & $\beta_{33}$ & $\beta_{12}$ & $\beta_{13}$ & $\beta_{23}$ \\
\hline$C(1)$ & $2482(3)$ & $8337(3)$ & 2389 (3) & $79(3)$ & $91(3)$ & $75(3)$ & $35(5)$ & $-5(5)$ & $42(5$ \\
\hline$C(2)$ & 3262 (3) & $8875(3)$ & $1678(3)$ & $59(3)$ & $96(3)$ & $97(4)$ & $13(4)$ & $-10(5)$ & $30(5)$ \\
\hline $\mathbf{C}(\mathbf{3})$ & 2967 (3) & $9224(3)$ & $639(3)$ & $60(2)$ & $91(3)$ & $90(4)$ & $-7(4)$ & $19(4)$ & $35(5)$ \\
\hline $\mathrm{C}(4)$ & $1841(3)$ & $9153(3)$ & $114(3)$ & $61(2)$ & $62(3)$ & $78(3)$ & $12(4)$ & $10(4)$ & $43(4)$ \\
\hline$C(5)$ & $1098(3)$ & $9071(3)$ & $1123(3)$ & $62(2)$ & $63(3)$ & $75(3)$ & $26(4)$ & $11(4)$ & $34(4)$ \\
\hline $\mathbf{C}(\mathbf{6})$ & $1379(3)$ & $8648(3)$ & 2267 (3) & $73(3)$ & $62(3)$ & $75(3)$ & $25(4)$ & $22(4)$ & $38(4)$ \\
\hline $\mathrm{O}(7)$ & $2735(2)$ & 7677 (3) & 3033 (3) & $106(3)$ & $168(4)$ & $148(4)$ & $90(5)$ & $15(4)$ & $178(6)$ \\
\hline$O(8)$ & $4268(2)$ & $8880(3)$ & $2190(3)$ & $65(2)$ & $162(3)$ & $137(3)$ & $24(4)$ & $-24(4)$ & $74(5)$ \\
\hline$C(9)$ & $5090(3)$ & $9322(4)$ & $1543(5)$ & $58(3)$ & $162(5)$ & $172(6)$ & $46(6)$ & $6(6)$ & $27(8)$ \\
\hline $\mathrm{C}(10)$ & $1526(3)$ & $8106(3)$ & $-1128(3)$ & $66(2)$ & $69(3)$ & $75(3)$ & $22(4)$ & $18(4)$ & $33(4)$ \\
\hline C(11) & $1594(4)$ & $6910(3)$ & $-823(4)$ & $120(4)$ & $70(3)$ & $107(4)$ & $34(5)$ & $20(6)$ & $25(5)$ \\
\hline$C(12)$ & $2278(3)$ & $8252(4)$ & $-2121(4)$ & $95(3)$ & $115(4)$ & $91(4)$ & $19(5)$ & $48(5)$ & $27(6)$ \\
\hline C(13) & $405(3)$ & $8105(3)$ & $-1696(4)$ & $83(3)$ & $97(4)$ & $103(4)$ & $21(5)$ & $-19(5)$ & $10(6)$ \\
\hline$O(14)$ & $1708(2)$ & $10228(2)$ & $-260(2)$ & $103(2)$ & $65(2)$ & $81(2)$ & $6(3)$ & $10(3)$ & $47(3)$ \\
\hline$O(15)$ & 1416 (2) & $9909(2)$ & 2347 (2) & $96(2)$ & 64 (2) & $85(2)$ & $23(3)$ & $28(3)$ & $29(3)$ \\
\hline$C(16)$ & $539(3)$ & $8133(3)$ & 2994 (3) & $86(3)$ & 87 (3) & $91(4)$ & $33(5)$ & $53(5)$ & $66(5)$ \\
\hline $\mathrm{C}(17)$ & $-577(3)$ & $8566(4)$ & 2768 (4) & $94(3)$ & $126(4)$ & $153(5)$ & $43(6)$ & $105(6)$ & $106(7)$ \\
\hline$C(18)$ & $917(4)$ & $8540(5)$ & $4424(4)$ & $145(5)$ & $171(6)$ & $89(4)$ & $50(8)$ & $91(7)$ & $87(8)$ \\
\hline$C(19)$ & 373 (4) & $6774(4)$ & $7(4)$ & $114(4)$ & 92 (4) & $163(5)$ & $13(6)$ & $93(7)$ & $106(7)$ \\
\hline$C^{\prime}(1)$ & $4257(3)$ & $13041(3)$ & 2299 (3) & $60(3)$ & $81(3)$ & $99(4)$ & $20(4)$ & $17(5)$ & $45(5)$ \\
\hline$C^{\prime}(2)$ & (3) & 125 & (3) & $62(2)$ & 65 & $97(4)$ & $12(4)$ & $-16(5)$ & $39(5)$ \\
\hline$C^{\prime}(3)$ & $3547(3)$ & 125 & (3) & 81 & 73 & $85(3)$ & $6(4)$ & $-8(5)$ & 66 \\
\hline$C^{\prime}(4)$ & 2555 (3) & (3) & (3) & 61 & 70 (3) & $75(3)$ & $-9(4)$ & $15(4)$ & $42(5$ \\
\hline$C^{\prime}(5)$ & $2382(3)$ & (3) & (3) & 55 & $67(3)$ & $73(3)$ & $5(4)$ & $8(4)$ & 32 \\
\hline$C^{\prime}(6)$ & (2) & $3(3)$ & (3) & 56 & $58(3)$ & 77 (3) & $4(4)$ & $10(4)$ & 35 \\
\hline$O^{\prime}(7)$ & $5033(2)$ & $13157(3)$ & $1761(3)$ & $71(2)$ & $218(4)$ & $168(4)$ & $82(5)$ & $73(4)$ & 188 \\
\hline$O^{\prime}(8)$ & $5181(2)$ & $12023(2)$ & 3519 (3) & $79(2)$ & $97(3)$ & $147(3)$ & $55(3)$ & $-20(4)$ & 74 \\
\hline$C^{\prime}(9)$ & $5357(4)$ & $11555(4)$ & $4584(5)$ & $107(4)$ & $141(5)$ & $182(6)$ & 83 (7) & $-52(7)$ & 143 (9 \\
\hline$C^{\prime}(10)$ & 2538 (3) & $14322(3)$ & 5098 (3) & $78(3)$ & $79(3)$ & $76(3)$ & $-4(4)$ & $18(4)$ & 24 \\
\hline$C^{\prime}(11)$ & 3339 (3) & $15316(3)$ & $4893(4)$ & $96(3)$ & $77(3)$ & $134(5)$ & $-21(5)$ & $31(6)$ & $-1(6$ \\
\hline$C^{\prime}(12)$ & $2814(4)$ & $14123(4)$ & $6428(4)$ & $121(4)$ & $132(4)$ & $75(4)$ & $13(6)$ & $10(6)$ & 24 \\
\hline$C^{\prime}(13)$ & $1432(3)$ & $14703(4)$ & 5036 (4) & $94(3)$ & $103(4)$ & $114(4)$ & $32(3)$ & $44(6)$ & 2016 \\
\hline$O^{\prime}(14)$ & $1676(2)$ & $12304(2)$ & $4182(2)$ & $81(2)$ & $85(2)$ & $97(3)$ & $-35(5)$ & 37 (3) & 44 \\
\hline $0^{\prime}(15)$ & $2393(2)$ & $12328(2)$ & $1672(2)$ & $72(2)$ & $67(2)$ & $82(2)$ & $-22(3)$ & $6(3)$ & $29(3$ \\
\hline & $3155(3)$ & $14021(3)$ & 797 (3) & $74(3)$ & $83(3)$ & $93(3)$ & $23(4)$ & $32(3)$ & 8015 \\
\hline C'i7i & 2042 (3) & $14298(4)$ & $528(4)$ & $103(4)$ & $131(4)$ & $128(5)$ & $69(6)$ & $24(6)$ & 147 \\
\hline & 3456 (3) & $13237(4)$ & $-424(4)$ & 107 (4) & $128(4)$ & $85(4)$ & $35(6)$ & $41(5)$ & 7516 \\
\hline$C^{\prime}(19)$ & 3906 (4) & $15199(4)$ & $1227(4)$ & $111(4)$ & $95(4)$ & $151(5)$ & $-13(6)$ & $50(7)$ & $102(7)$ \\
\hline
\end{tabular}

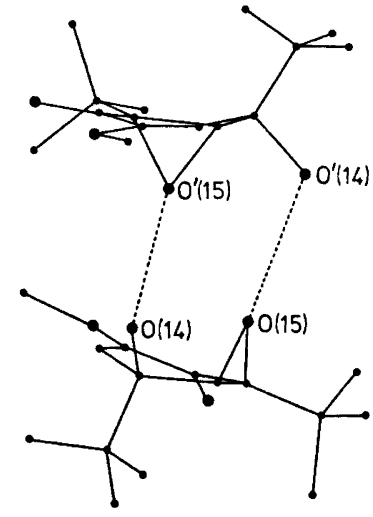

these hydrogen bonds are probably responsible for the boat conformation of the cyclohexene ring.

As part of a series of investigations on oxidation products of phenols, the crystal structure of the autooxidation product of 4,6-di-t-butylguaiacol in alkaline solution has been deter. mined.

Butylated hydroxyanisoles (BHA) are used extensively as antioxidants in food.1,2 The aim of this investigations was to establish the

Fig. 2. The hydrogen-bonding system in the dimer molecule.

Acta Chem. Scand. B 29 (1975) No. 5 
Table 3. Positional parameters $\left(\times 10^{3}\right)$ of the hydrogen atoms.

\begin{tabular}{|c|c|c|c|c|c|c|c|}
\hline & $x$ & $y$ & $z$ & & $x$ & $y$ & $z$ \\
\hline $\mathrm{H}(\mathrm{C} 3)$ & 353 & 954 & 18 & $\mathrm{H}\left(\mathrm{C}^{\prime} \mathbf{3}\right)$ & 356 & 1228 & 493 \\
\hline H(C5) & 34 & 906 & 81 & $\mathbf{H}\left(\mathbf{C}^{\prime} \mathbf{5}\right)$ & 175 & 1382 & 259 \\
\hline Hi (C9) & 499 & 1027 & 158 & $\mathrm{H} \mathbf{l}\left(\mathrm{C}^{\prime} \mathbf{9}\right)$ & 480 & 1096 & 463 \\
\hline H2(C9) & 507 & 882 & 66 & $\mathrm{H} 2\left(\mathrm{C}^{\prime} 9\right)$ & 532 & 1210 & 548 \\
\hline H3(C9) & 571 & 921 & 197 & $\mathbf{H} 3\left(\mathrm{C}^{\prime} \mathbf{9}\right)$ & 598 & 1126 & 465 \\
\hline Hl(CI1) & 137 & 628 & -156 & $\mathrm{Hl}\left(\mathrm{C}^{\prime} 11\right)$ & 306 & 1553 & 406 \\
\hline H2(C11) & 240 & 693 & -53 & $\mathrm{H} 2\left(\mathrm{C}^{\prime} 11\right)$ & 338 & 1596 & 561 \\
\hline H3(C11) & 111 & 679 & -23 & $\mathrm{H} 3\left(\mathrm{C}^{\prime} 11\right)$ & 397 & 1501 & 488 \\
\hline $\mathrm{Hl}(\mathrm{Cl2})$ & 208 & 759 & -291 & $\mathrm{HI}\left(\mathrm{C}^{\prime} 12\right)$ & 275 & 1482 & 707 \\
\hline $\mathrm{H} 2$ (C12) & 229 & 893 & -234 & $\mathrm{H} 2\left(\mathrm{C}^{\prime} 12\right)$ & 359 & 1401 & 659 \\
\hline H3(C12) & 303 & 813 & -190 & $\mathrm{H} 3\left(\mathrm{C}^{\prime} 12\right)$ & 230 & 1348 & 660 \\
\hline Hl(C13) & 31 & 868 & -186 & $\mathrm{H} 1\left(\mathrm{C}^{\prime} 13\right)$ & 88 & 1402 & 508 \\
\hline $\mathrm{H} 2(\mathrm{Cl3})$ & 27 & 761 & -249 & $\mathrm{H} 2\left(\mathrm{C}^{\prime} 13\right)$ & 120 & 1488 & 413 \\
\hline H3(C13) & 15 & 800 & -115 & H3 $\left(\mathrm{C}^{\prime} 13\right)$ & 141 & 1543 & 575 \\
\hline $\mathrm{H}(\mathrm{O} 14)$ & 189 & 1093 & 46 & $\overrightarrow{\mathrm{H}}\left(\mathrm{O}^{\prime} 14\right)^{\prime}$ & 163 & 1155 & 346 \\
\hline $\mathrm{Hi}$ (CI7) & -85 & 833 & 189 & $\mathrm{Hi}\left(\mathrm{C}^{\prime} 17\right)$ & 184 & 1489 & 128 \\
\hline H2(C17) & -103 & 834 & 323 & $\mathrm{H} 2\left(\mathrm{C}^{\prime} 17\right)$ & 159 & 1365 & 39 \\
\hline H3(C17) & -142 & 932 & 304 & H3 (C'17) & 203 & 1468 & -24 \\
\hline $\mathrm{Hl}(\mathrm{Cl} 18)$ & 160 & 811 & 467 & $\mathrm{Hl}\left(\mathrm{C}^{\prime} 18\right)$ & 418 & 1312 & -37 \\
\hline $\mathrm{H} 2(\mathrm{C} 18)$ & 49 & 834 & 485 & $\mathrm{H} 2\left(\mathrm{C}^{\prime} 18\right)$ & 341 & 1350 & -117 \\
\hline H3(C18) & 104 & 947 & 487 & H3(C'18) & 299 & 1246 & -76 \\
\hline H1(C19) & 22 & 655 & 175 & Hl $\left(C^{\prime} 19\right)$ & 386 & 1564 & 61 \\
\hline H2(C19) & 102 & 644 & 264 & H2(C'19) & 370 & 1574 & 201 \\
\hline H3(C19) & 14 & 639 & 280 & H3 $\left(C^{\prime} 19\right)$ & 451 & 1517 & 147 \\
\hline
\end{tabular}

structure and stereochemistry of the epoxide formed upon oxidation of 4,6-di-t-butylguaiacol to gain information concerning the mechanism of formation of the epoxide. ${ }^{1-8}$

\section{EXPERIMENTAL}

Intensities were measured with monochromated $\mathrm{Cu} K \alpha$ radiation by a computer-controlled

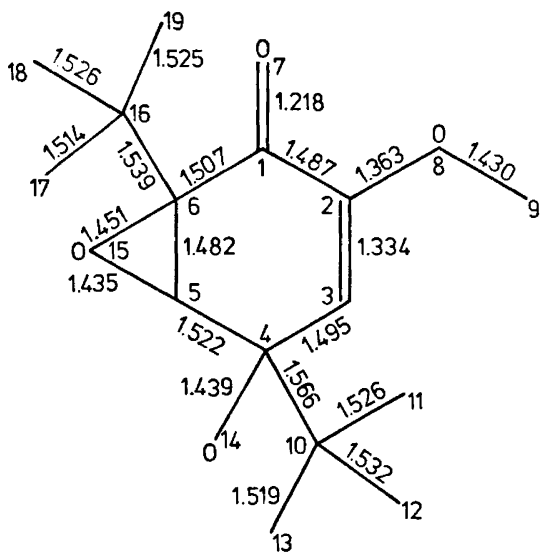

Fig. 3. The interatomic bond distances.

Acta Chem. Scand. B 29 (1975) No. 5
Philips PW 1100 diffractometer. Unit-cell dimensions were determined by measurement of the angular positions of 25 accurately centered reflexions found by the "Peak Hunting Program". The unit cell and orientation parameters were obtained from these angular coordinates by the method of least squares. Crystal data are: space group $P \overline{1}, a=12.833(2), b=11.695(2), c=$ 10.861 (2) $\AA, \alpha=104.49$ (2), $\beta=94.62$ (2), $\gamma=$ $96.83(2)^{\circ}, V=1299 \AA^{3}, Z=4, D_{\mathrm{c}}=1.371 \mathrm{~g} \mathrm{~cm}^{-3}$. The $\theta-2 \theta$ scan technique was employed to

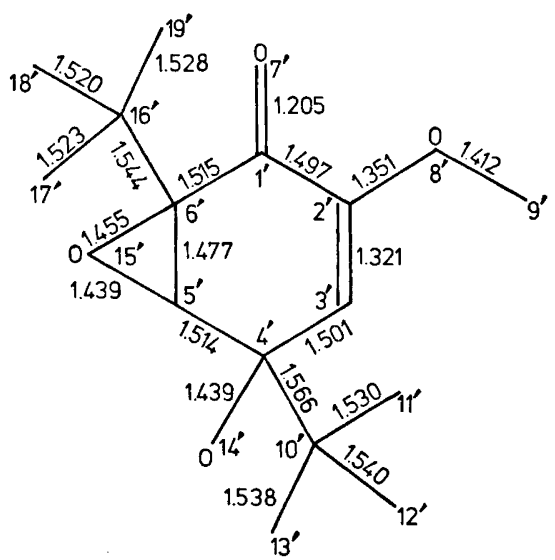


Table 4. Observed and calculated structure amplitudes. The columns use the running index $k$, $10\left|F_{\mathrm{o}}\right|$, and $10\left|F_{\mathrm{c}}\right|$, respectively.

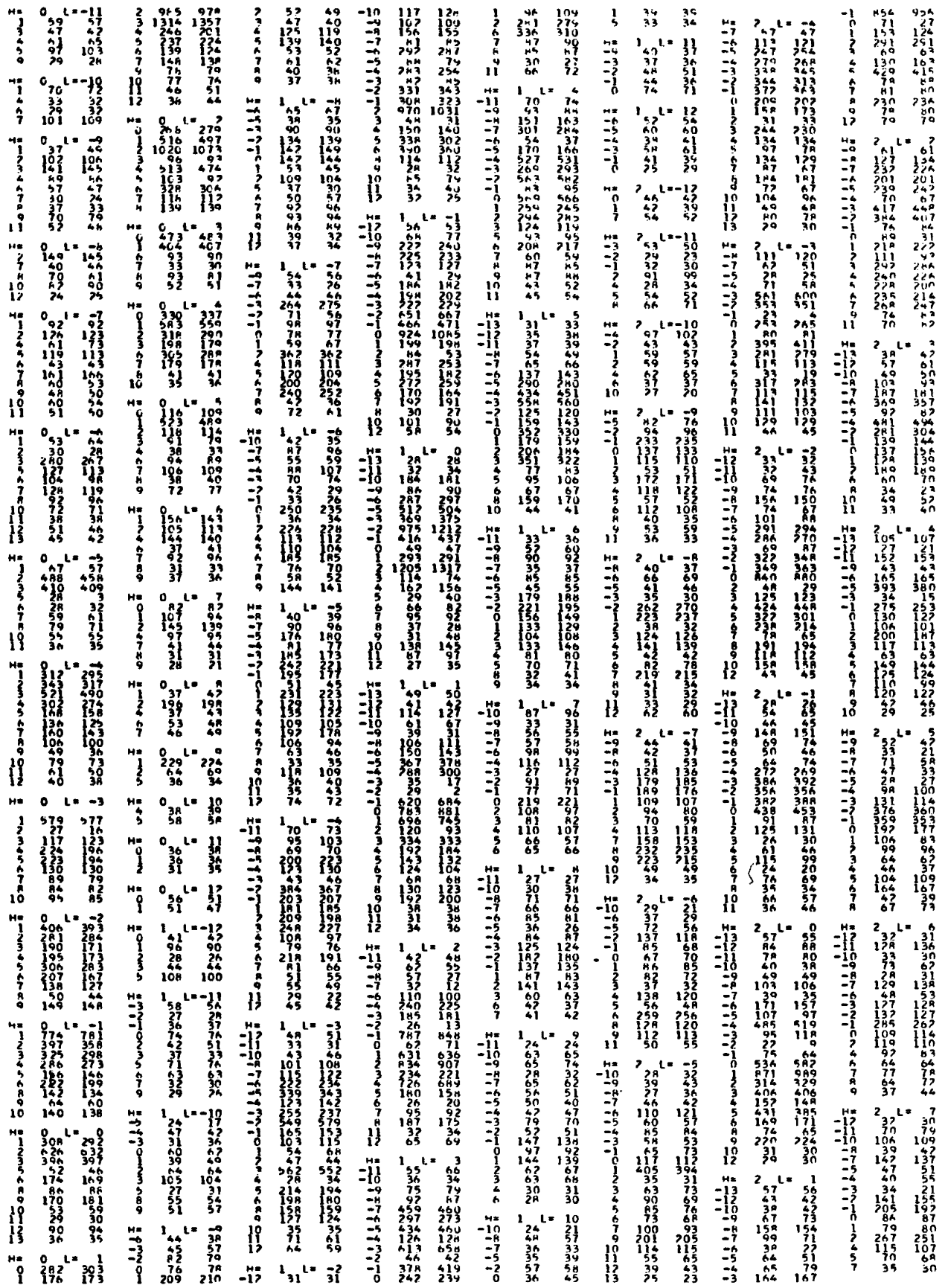


Table 4. Continued.

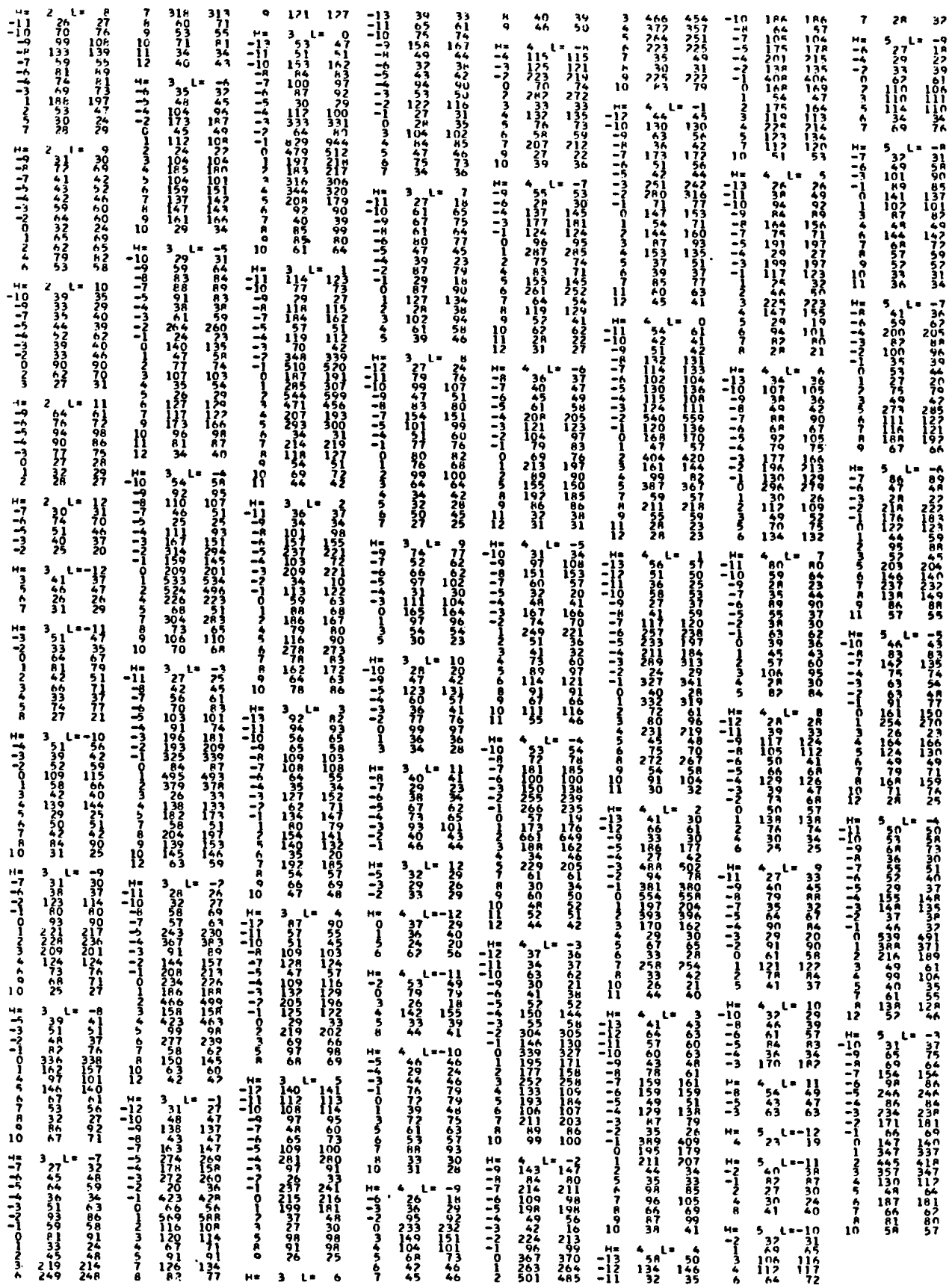

Acta Chem. Scand. B 29 (1975) No. 5 
Table 4. Continued.

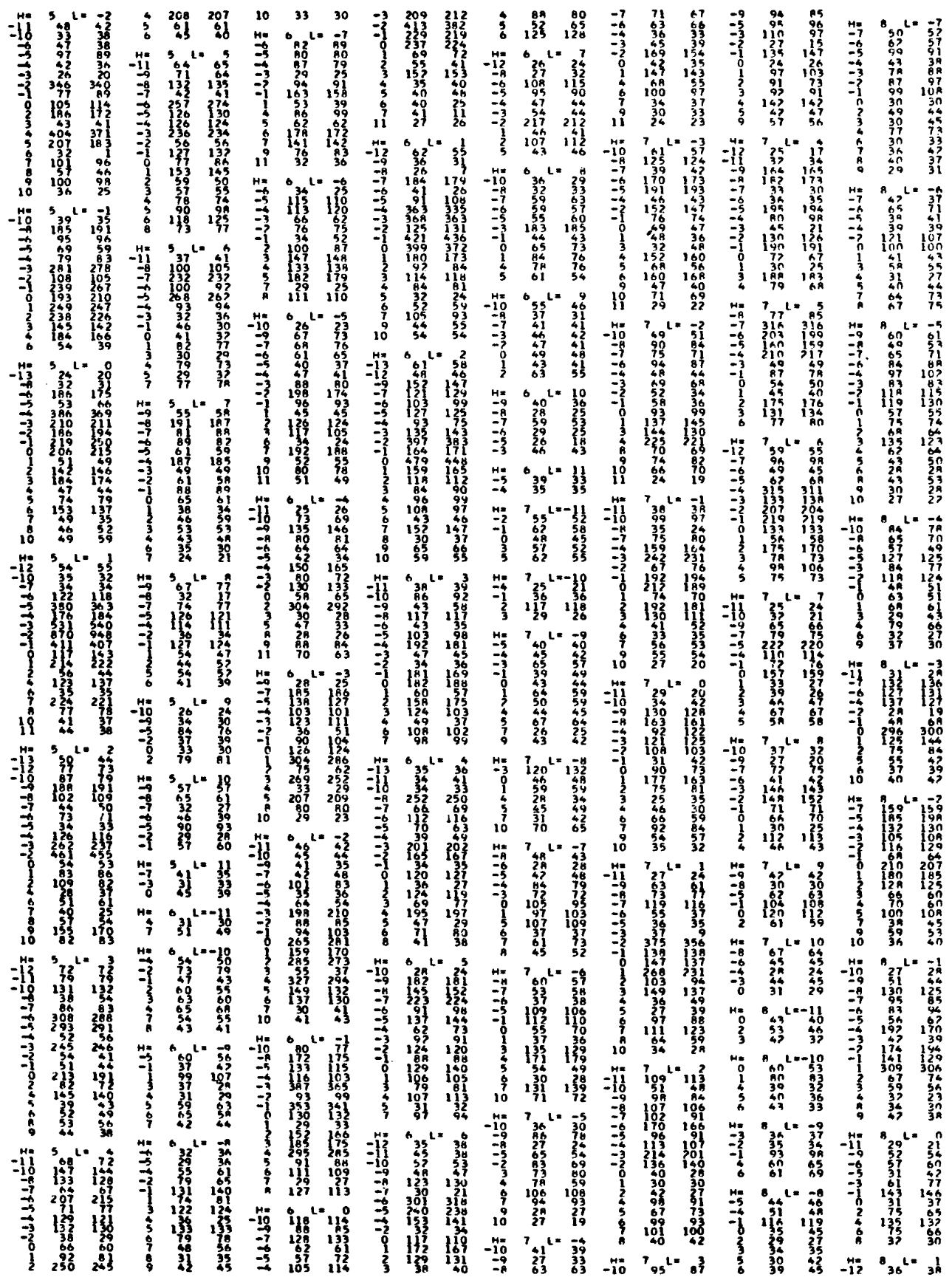


Table 4. Continued.

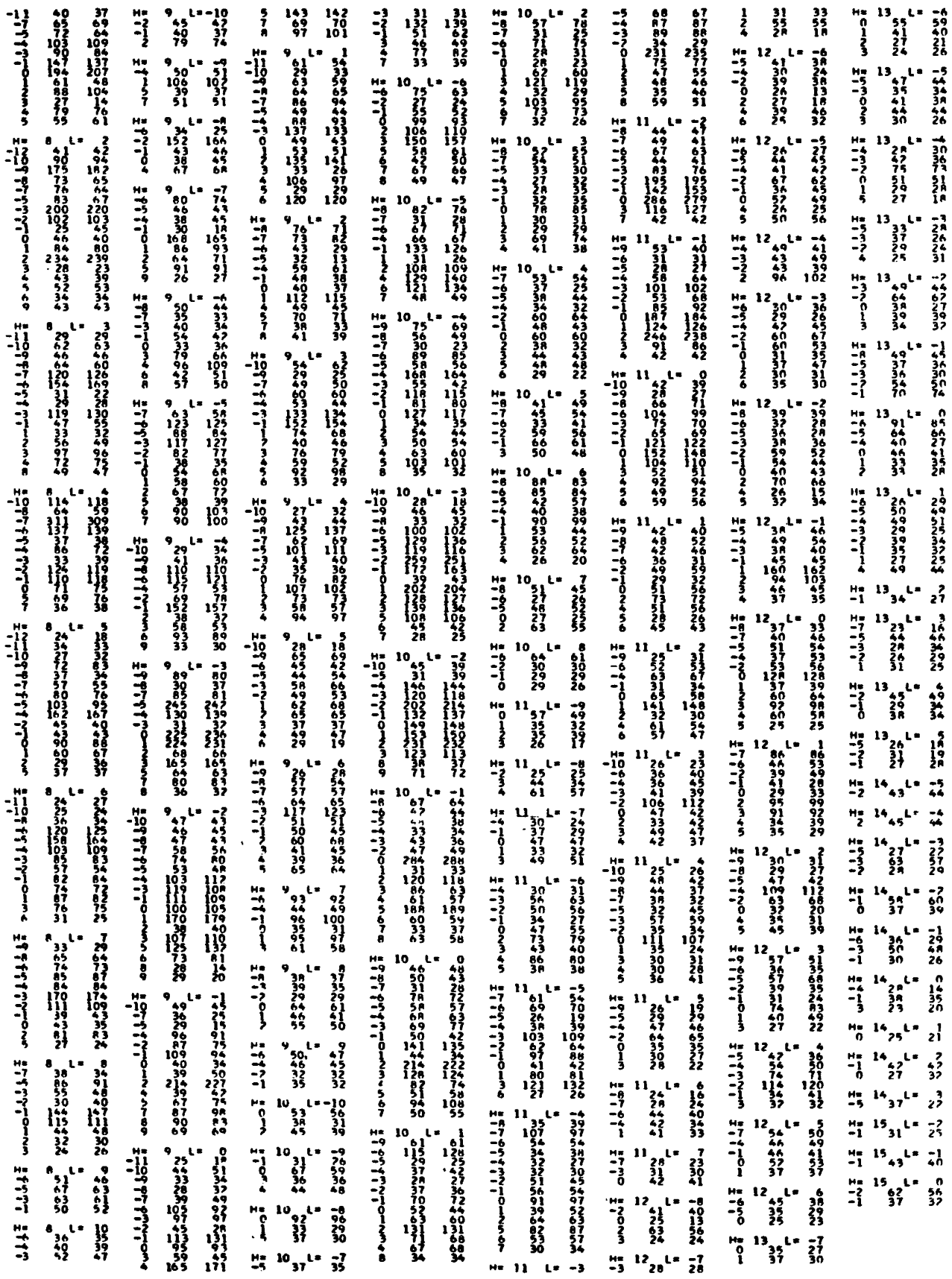


measure 5274 reflexions out to $\theta=65^{\circ}$ at a scan speed of 0.026 degrees per second. Backgrounds were estimated by stationary counting at $\pm 0.75^{\circ}$ $2 \theta$ from the peak maxima. Three monitor reflexions were measured every $90 \mathrm{~min}$. Lorentz and polarization corrections were applied to the data but no correction for absorption was made. The 3546 reflexions for which $\sigma(I) / I \leq 0.25$, where $I$ is the net intensity and $\sigma(I)$ its estimated standard deviation, based on counter statistics, were used in refinement of the structure.

\section{STRUCTURE DETERMINATION AND REFINEMENTS}

The absolute scale and overall temperature factor for calculation of normalized structure factor magnitudes, $|E|$, were estimated by Wilson's method. ${ }^{4}$ The structure was solved by a modified version of the MULTAN direct phase determination procedure ${ }^{5}$ from the 358 reflexions with $|E|$ values $\geq 1.85$. The three origin specifying reflexions and five reflexions used as variables in the starting set of phases are given in Table 1. An $E$ map computed with the signs of the most reliable set showed all the non-hydrogen atoms.

The positional parameters and isotropic temperature factors of all the 38 non-hydrogen atoms were subjected to four cycles of fullmatrix least-squares refinement $(R=0.164)$ by a modified version of the program LALS. $^{6}$ A
Hughes" weighting scheme was used in the refinement. One cycle of refinement of the nonhydrogen atoms with anisotropic temperature factors reduced $R$ to 0.095 . A difference Fourier synthesis computed at this point revealed the positions of all the hydrogen atoms. Additional cycles of least-squares calculations with hydrogen atoms included with fixed positional and thermal $\left(B=3.5 \AA^{2}\right)$ parameters reduced $R$ to 0.062 for 3546 reflexions. Freeman's ${ }^{8}$ scattering factors for oxygen and carbon and that of Stewart, Davidson and Simpson ${ }^{\circ}$ for hydrogen, were used throughout the analysis.

The final positional and thermal parameters of the non-hydrogen atoms, together with their standard deviations, are listed in Table 2 and those of the hydrogen atoms in Table 3. A list of the observed and calculated structure amplitudes is given in Table 4.

\section{RESULTS AND DISCUSSION}

The autooxidation product of 4,6-di-t-butylguaiacol in alkaline solution was established to be 5,6-epoxy-4-hydroxy-2-methoxy-4,6-di-t-

butylcyclohex-2-enone with the hydroxyl group and epoxide ring cis to each other. The molecular structure is shown in Fig. 1; the two molecules are identically numbered, with the numbers of one distinguished by primes.

Table 5. Bond distances $(\AA)$ between non-hydrogen atoms, with estimated standard deviations in parentheses.

$\begin{array}{llll}C(1)-C(2) & 1.487(4) & C^{\prime}(1)-C^{\prime}(2) & 1.497(4) \\ C(1)-C(6) & 1.507(4) & C^{\prime}(1)-C^{\prime}(6) & 1.515(4) \\ C(1)-O(7) & 1.218(4) & C^{\prime}(1)-O^{\prime}(7) & 1.205(4) \\ C(2)-C(3) & 1.334(4) & C^{\prime}(2)-C^{\prime}(3) & 1.321(4) \\ C(2)-O(8) & 1.363(4) & C^{\prime}(2)-O^{\prime}(8) & 1.351(4) \\ C(3)-C(4) & 1.495(4) & C^{\prime}(3)-C^{\prime}(4) & 1.501(4) \\ C(4)-C(5) & 1.522(4) & C^{\prime}(4)-C^{\prime}(5) & 1.514(4) \\ C(4)-C(10) & 1.566(4) & C^{\prime}(4)-C^{\prime}(10) & 1.566(4) \\ C(4)-O(14) & 1.439(3) & C^{\prime}(4)-O^{\prime}(14) & 1.439(4) \\ C(5)-C(6) & 1.482(4) & C^{\prime}(5)-C^{\prime}(6) & 1.477(4) \\ C(5)-O(15) & 1.435(3) & C^{\prime}(5)-O^{\prime}(15) & 1.439(3) \\ C(6)-O(15) & 1.451(3) & C^{\prime}(6)-O^{\prime}(15) & 1.455(3) \\ C(6)-C(16) & 1.539(4) & C^{\prime}(6)-C^{\prime}(16) & 1.544(4) \\ O(8)-C(9) & 1.430(5) & O^{\prime}(8)-C^{\prime}(9) & 1.412(5) \\ C(10)-C(11) & 1.526(4) & C^{\prime}(10)-C^{\prime}(11) & 1.530(5) \\ C(10)-C(12) & 1.532(5) & C^{\prime}(10)-C^{\prime}(12) & 1.540(5) \\ C(10)-C(13) & 1.519(5) & C^{\prime}(10)-C^{\prime}(13) & 1.538(5) \\ C(16)-C(17) & 1.514(5) & C^{\prime}(16)-C^{\prime}(17) & 1.523(5) \\ C(16)-C(18) & 1.526(5) & C^{\prime}(16)-C^{\prime}(18) & 1.520(5) \\ C(16)-C(19) & 1.525(5) & C^{\prime}(16)-C^{\prime}(19) & 1.528(5)\end{array}$


Table 6. Interatomic angles $\left({ }^{\circ}\right)$, with estimated standard deviations in parentheses.

\begin{tabular}{|c|c|c|c|}
\hline $\begin{array}{l}C(2)-C(1)-C(6) \\
C(2)-C(1)-O(7) \\
C(6)-C(1)-O(7) \\
C(1)-C(2)-C(3) \\
C(1)-C(2)-O(8) \\
C(3)-C(2)-O(8) \\
C(2)-C(3)-C(4) \\
C(3)-C(4)-C(5) \\
C(3)-C(4)-C(10) \\
C(3)-C(4)-O(14) \\
C(5)-C(4)-C(10) \\
C(5)-C(4)-O(14) \\
C(10)-C(4)-O(14) \\
C(4)-C(5)-C(6) \\
C(4)-C(5)-O(15) \\
C(6)-C(5)-O(15) \\
C(1)-C(6)-C(5) \\
C(1)-C(6)-O(15) \\
C(1)-C(6)-C(16) \\
C(5)-C(6)-O(15) \\
C(5)-C(6)-C(16) \\
O(15)-C(6)-C(16) \\
C(2)-O(8)-C(9) \\
C(4)-C(10)-C(11) \\
C(4)-C(10)-C(12) \\
C(4)-C(10)-C(13) \\
C(11)-C(10)-C(12) \\
C(11)-C(10)-C(13) \\
C(12)-C(10)-C(13) \\
C(5)-O(15)-C(6) \\
C(6)-C(16)-C(17) \\
C(6)-C(16)-C(18) \\
C(6)-C(16)-C(19) \\
C(17)-C(16)-C(18) \\
C(17)-C(16)-C(19) \\
C(18)-C(16)-C(19)\end{array}$ & $\begin{array}{r}116.8(3) \\
120.9(3) \\
122.3(3) \\
122.0(3) \\
110.7(3) \\
127.1(3) \\
123.8(3) \\
111.3(3) \\
111.6(3) \\
109.1(3) \\
111.8(3) \\
106.8(3) \\
105.9(2) \\
123.4(3) \\
114.9(3) \\
59.6(2) \\
114.8(3) \\
110.2(3) \\
119.3(3) \\
58.5(2) \\
122.4(3) \\
115.2(3) \\
115.8(3) \\
110.2(3) \\
109.6(3) \\
110.7(3) \\
109.1(3) \\
108.7(3) \\
108.7(3) \\
61.8(2) \\
112.5(3) \\
108.8(3) \\
109.5(3) \\
108.3(3) \\
107.5(3) \\
110.2(3)\end{array}$ & $\begin{array}{l}C^{\prime}(2)-C^{\prime}(1)-C^{\prime}(6) \\
C^{\prime}(2)-C^{\prime}(1)-O^{\prime}(7) \\
C^{\prime}(6)-C^{\prime}(1)-O^{\prime}(7) \\
C^{\prime}(1)-C^{\prime}(2)-C^{\prime}(3) \\
C^{\prime}(1)-C^{\prime}(2)-O^{\prime}(8) \\
C^{\prime}(3)-C^{\prime}(2)-O^{\prime}(8) \\
C^{\prime}(2)-C^{\prime}(3)-C^{\prime}(4) \\
C^{\prime}(3)-C^{\prime}(4)-C^{\prime}(5) \\
C^{\prime}(3)-C^{\prime}(4)-C^{\prime}(10) \\
C^{\prime}(3)-C^{\prime}(4)-O^{\prime}(14) \\
C^{\prime}(5)-C^{\prime}(4)-C^{\prime}(10) \\
C^{\prime}(5)-C^{\prime}(4)-O^{\prime}(14) \\
C^{\prime}(10)-C^{\prime}(4)-O^{\prime}(14) \\
C^{\prime}(4)-C^{\prime}(5)-C^{\prime}(6) \\
C^{\prime}(4)-C^{\prime}(5)-O^{\prime}(15) \\
C^{\prime}(6)-C^{\prime}(5)-O^{\prime}(15) \\
C^{\prime}(1)-C^{\prime}(6)-C^{\prime}(5) \\
C^{\prime}(1)-C^{\prime}(6)-O^{\prime}(15) \\
C^{\prime}(1)-C^{\prime}(6)-C^{\prime}(16) \\
C^{\prime}(5)-C^{\prime}(6)-O^{\prime}(15) \\
C^{\prime}(5)-C^{\prime}(6)-C^{\prime}(16) \\
O^{\prime}(15)-C^{\prime}(6)-C^{\prime}(16) \\
C^{\prime}(2)-O^{\prime}(8)-C^{\prime}(9) \\
C^{\prime}(4)-C^{\prime}(10)-C^{\prime}(11) \\
C^{\prime}(4)-C^{\prime}(10)-C^{\prime}(12) \\
C^{\prime}(4)-C^{\prime}(10)-C^{\prime}(13) \\
C^{\prime}(11)-C^{\prime}(10)-C^{\prime}(12) \\
C^{\prime}(11)-C^{\prime}(10)-C^{\prime}(13) \\
C^{\prime}(12)-C^{\prime}(10)-C^{\prime}(13) \\
C^{\prime}(5)-O^{\prime}(15)-C^{\prime}(6) \\
C^{\prime}(6)-C^{\prime}(16)-C^{\prime}(17) \\
C^{\prime}(6)-C^{\prime}(16)-C^{\prime}(18) \\
C^{\prime}(6)-C^{\prime}(16)-C^{\prime}(19) \\
C^{\prime}(17)-C^{\prime}(16)-C^{\prime}(18) \\
C^{\prime}(17)-C^{\prime}(16)-C^{\prime}(19) \\
C^{\prime}(18)-C^{\prime}(16)-C^{\prime}(19)\end{array}$ & $\begin{array}{r}116.7(3) \\
120.4(3) \\
122.9(3) \\
122.5(3) \\
110.0(3) \\
127.4(3) \\
125.6(3) \\
111.2(3) \\
113.0(3) \\
108.2(3) \\
109.6(3) \\
108.0(3) \\
106.6(3) \\
124.4(3) \\
115.6(3) \\
59.8(2) \\
116.1(3) \\
109.2(2) \\
118.7(3) \\
58.8(2) \\
122.4(3) \\
115.2(3) \\
116.7(3) \\
110.1(3) \\
109.1(3) \\
110.4(3) \\
109.7(3) \\
108.8(3) \\
108.7(3) \\
61.4(2) \\
110.7(3) \\
109.2(3) \\
109.6(3) \\
108.5(3) \\
108.3(3) \\
110.5(3)\end{array}$ \\
\hline
\end{tabular}

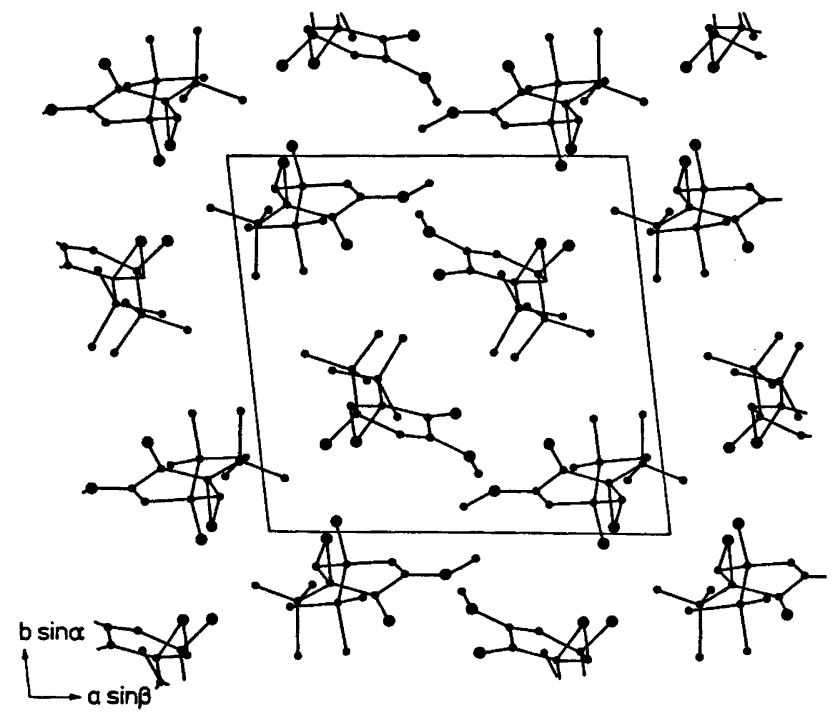

Fig. 4. Projection of the crystal structure along the $c$ direction. $\bullet$, carbon; $\bullet$, oxygen.

Acta Chem. Scand. B 29 (1975) No. 5 
Table 7. Intermolecular distances shorter than 3. 8 A.

\begin{tabular}{|c|c|c|c|}
\hline Superscript & Coordinates & Superscript & Coordinates \\
\hline $\begin{array}{l}\text { none } \\
\text { i } \\
\text { ii }\end{array}$ & $\begin{array}{rrr}x ; & y ; & z \\
x ; & -1+y ; & z \\
-x ; & 2-y ; & -z\end{array}$ & $\begin{array}{l}\text { iii } \\
\text { iv } \\
\text { v }\end{array}$ & $\begin{array}{l}1-x ; 2-y ; 1-z \\
1-x ; 2-y ; 1-z \\
1-x ; 3-y ; 1-z\end{array}$ \\
\hline $\begin{array}{l}C(13)-O\left(15^{\mathrm{ii}}\right. \\
O(14)-C^{\prime}\left(17^{\mathrm{ii}}\right. \\
C(3)-O^{\prime}(15) \\
C(4)-O^{\prime}(15) \\
O(7)-C^{\prime}\left(9^{\mathrm{iv}}\right) \\
O(7)-C^{\prime}\left(19^{\mathrm{i}}\right) \\
O(8)-O^{\prime}(8) \\
O(8)-C^{\prime}(9) \\
O(8)-C^{\prime}\left(9^{\mathrm{iv}}\right) \\
C(9)-O^{\prime}(8) \\
C(9)-C^{\prime}(9) \\
C(9)-C^{\prime}\left(18^{\mathrm{iii}}\right.\end{array}$ & i) $\begin{array}{l}3.632(4) \\
3.645(5) \\
3.703(4) \\
3.632(3) \\
3.285(5) \\
3.629(5) \\
3.608(4) \\
3.579(5) \\
3.666(5) \\
3.328(5) \\
\text { ii) } 3.624(6) \\
3.713(6)\end{array}$ & $\begin{array}{l}C(11)-C^{\prime}\left(17^{\mathrm{i}}\right) \\
C(12)-O^{\prime}\left(8^{\mathrm{iii}}\right) \\
C(13)-C^{\prime}\left(5^{\mathrm{ii}}\right) \\
C(13)-O^{\prime}\left(14^{\mathrm{ii}}\right) \\
C(13)-O^{\prime}\left(15^{\mathrm{ii}}\right) \\
O(14)-O^{\prime}(15) \\
O(15)-O^{\prime}(14) \\
O(15)-O^{\prime}(15) \\
C^{\prime}(2)-C^{\prime}\left(11^{\mathrm{v}}\right) \\
O^{\prime}(8)-C^{\prime}\left(11^{\mathrm{v}}\right) \\
C^{\prime}(9)-C^{\prime}\left(11^{\mathrm{v}}\right)\end{array}$ & $\begin{array}{l}3.788(5) \\
3.720(4) \\
3.728(4) \\
3.541(4) \\
3.569(4) \\
2.797(3) \\
2.967(3) \\
3.233(3) \\
3.740(5) \\
3.413(4) \\
3.724(6)\end{array}$ \\
\hline
\end{tabular}

Table 8. Least-squares planes and deviations ( $\AA$ ). The planes are described in terms of normalized equations in the orthogonal coordinate system $(m, n, p)$ having $p \| c, n$ in the bc plane and $m$ in the $a, b, c$-octant.

\begin{tabular}{|c|c|c|c|c|c|}
\hline $\begin{array}{l}\text { Plane A } \\
\text { Plane B } \\
\text { Plane C } \\
\text { Plane A } \\
\text { Plane B } \\
\text { Plane C }\end{array}$ & \multicolumn{3}{|c|}{$\begin{aligned} 0.1693 m+0.9350 n+0.3154 p & =9.1427 \\
0.3487 m+0.9027 n+0.2522 & =9.1738 \\
-0.0403 m+0.9264 n+0.3745 p & =8.1605 \\
0.3964 m+0.8868 n+0.2375 p & =13.9480 \\
0.3145 m+0.9375 n+0.1489 p & =14.5499 \\
0.4577 m+0.8169 n+0.3263 p & =13.4030\end{aligned}$} & & \\
\hline \multicolumn{2}{|c|}{$\begin{array}{lc}\text { Plane } \mathrm{A} \\
\text { Atom } & \text { Deviation } \\
\mathrm{C}(1)^{a} & -0.267 \\
\mathrm{C}(2) & 0.009 \\
\mathrm{C}(3) & -0.009 \\
\mathrm{C}(4)^{a} & -0.258 \\
\mathrm{C}(5) & 0.008 \\
\mathrm{C}(6) & -0.008\end{array}$} & \multicolumn{2}{|c|}{\begin{tabular}{lc}
\multicolumn{2}{c}{ Plane B } \\
Atom & Deviation \\
C(1) & 0.004 \\
C(2) & 0.513 \\
C(3) & 0.487 \\
C(4) & -0.005 \\
C(5) & 0.009 \\
C(6) & -0.009
\end{tabular}} & \multicolumn{2}{|c|}{$\begin{array}{lr}\text { Plane } \mathrm{C} & \\
\text { Atom } & \text { Deviation } \\
\text { C(1) } & 0.004 \\
\text { C(2) } & 0.009 \\
\text { C(3) } & -0.009 \\
\text { C(4) } & 0.004 \\
\text { C(5) } & 0.531 \\
\text { C(6) } & 0.525\end{array}$} \\
\hline $\begin{array}{l}\text { Plane } A^{\prime} \\
\text { Atom I } \\
C^{\prime}(1)^{a} \\
C^{\prime}(2) \\
C^{\prime}(3) \\
C^{\prime}(4)^{a} \\
C^{\prime}(5) \\
C^{\prime}(6)\end{array}$ & $\begin{array}{c}\mathbf{A}^{\prime} \\
\text { Deviation } \\
0.169 \\
-0.022 \\
0.022 \\
0.172 \\
-0.020 \\
0.019\end{array}$ & $\begin{array}{l}\text { Plane B } \\
\text { Atom } \\
C^{\prime}(1) \\
C^{\prime}(2)^{a} \\
C^{\prime}(3)^{a} \\
C^{\prime}(4) \\
C^{\prime}(5) \\
C^{\prime}(6)\end{array}$ & $\begin{array}{l}3^{\prime} \\
\text { Deviation } \\
-0.009 \\
-0.355 \\
-0.303 \\
0.010 \\
-0.020 \\
0.019\end{array}$ & \multicolumn{2}{|c|}{$\begin{array}{lr}\text { Plane } C^{\prime} \\
\text { Atom } & \text { Deviation } \\
C^{\prime}(1) & 0.007 \\
C^{\prime}(2) & -0.017 \\
C^{\prime}(3) & 0.017 \\
C^{\prime}(4) & -0.008 \\
C^{\prime}(5)^{a} & -0.367 \\
C^{\prime}(6)^{a} & -0.328\end{array}$} \\
\hline
\end{tabular}

a These atoms were omitted from the calculations of the least-squares planes.

The crystallographic asymmetric unit contains two molecules joined together by two hydrogen-bonds (Fig. 2). The hydroxyl oxygen $O(14)$ in one molecule is hydrogen-bonded to the epoxide oxygen $O^{\prime}(15)$ of the other. The distances $\mathrm{O}^{\prime}(15) \cdots \mathrm{H}(\mathrm{O} 14)$ and $\mathrm{O}(15) \cdots \mathrm{H}\left(\mathrm{O}^{\prime} 14\right)$ are 1.83 and $1.97 \AA$, respectively, and the angles $\mathrm{O}^{\prime}(15) \cdots \mathrm{H}(\mathrm{O} 14)-\mathrm{O}(14)$ and $\mathrm{O}(15) \cdots$ $\mathrm{H}\left(\mathrm{O}^{\prime} 14\right)-\mathrm{O}^{\prime}(14)$ are 171 and $167^{\circ}$, respectively. Fig. 3 indicates the numbering system used in Acta Chem. Scand. B 29 (1975) No. 5 
all tables and shows the bond lengths within the two molecules. Bond distances and angles for the structure are listed in Tables 5 and 6 . No correction for thermal vibrations have been made. The estimated standard deviations, based solely on least-squares parameters, are about $0.004 \AA$ for the bonds and $0.3^{\circ}$ for the angles. No distance between bonded non-hydrogen atoms in one molecule of the asymmetric unit differs by more than $0.019 \AA$ from the corresponding distance in the other molecule.

The mean $\mathrm{C}\left(s p^{3}\right)-\mathrm{C}\left(s p^{3}\right)$ bond distance, excluding $\mathrm{C}(5)-\mathrm{C}(6)$, is $1.532 \AA$. The longer bonds are between the highly substituted carbon atoms $\mathrm{C}(4), \mathrm{C}(10)$ and $\mathrm{C}(6), \mathrm{C}(16)$. The shortness of the $\mathrm{C}(5)-\mathrm{C}(6)$ bond length reflects the strain caused by the epoxide ring. The $\mathrm{C}\left(s p^{2}\right)-\mathrm{C}\left(s p^{3}\right)$ bonds have an average length of $1.504 \AA$ in good agreement with usually observed values. The $\mathrm{C}\left(s p^{2}\right)-\mathrm{C}\left(s p^{2}\right)$ single bond is slightly shorter, 1.492 $\AA$. The $\mathrm{C}\left(s p^{3}\right)-\mathrm{O}$ bonds and the $\mathrm{C}\left(s p^{2}\right)-\mathrm{O}$ bond have mean lengths of 1.430 and $1.357 \AA$, respectively.

The molecular packing is shown in Fig. 4. Intermolecular contacts less than $3.8 \AA$ are listed in Table 7. The hydrogen-bonded dimers are held in position in the unit cell by van der Waals forces. Some of the van der Waals distances are shorter than normal, for example the $\mathrm{O}(7)-\mathrm{C}^{\prime}\left(\mathbf{9}^{\mathrm{iv}}\right)$ distance of $3.285 \AA$.

The best least-square planes through the ring are given for each of the dimer molecules in Table 8. In the non-primed molecule, the sets of atoms $\mathrm{C}(1), \mathrm{C}(2), \mathrm{C}(3), \mathrm{C}(4) ; \mathrm{C}(1), \mathrm{C}(4)$, $\mathrm{C}(5), \mathrm{C}(6)$; and $\mathrm{C}(2), \mathrm{C}(3), \mathrm{C}(5), \mathrm{C}(6)$ are each coplanar within $\pm 0.009 \AA$. In the primed molecule the deviations from the best planes for the same sets of atoms are $\pm 0.017, \pm 0.020$, and $\pm 0.022 \AA$, respectively. All hydrogen atoms lie in chemically reasonable positions with apparent bond distances ranging from 0.76 to 1.12 $\AA$, mean value $0.96 \AA$.

The present investigation has received financial support from the Tri-Centennial Fund of the Bank of Sweden and from the Swedish Natural Science Research Council.

The authors are grateful to Professor Peder Kierkegaard for his active and stimulating interest in the work, to Dr. Finn Imsgard for valuable discussions and for the supply of crystals used in the work, and to Dr. Don Koenig for correcting the English of the paper.

\section{REFERENCES}

1. Hewgill, F. R. and Lee, S. L. J. Chem. Soc. C (1968) 1549.

2. Hewgill, F. R. and Lee, S. L. J. Chem. Soc. $C$ (1969) 2080.

3. Saito, I., Yoshimura, N., Arai, T., Omura, K., Nishinaga, A. and Matsuura, T. Tetrahedron 28 (1972) 5131.

4. Wilson, A. J. C. Nature (London) 150 (1942) 151.

5. Germain, G., Main, P. and Woolfson, M. M. Acta Crystallogr. B 26 (1970) 274.

6. Gantzel, P. K., Sparks, R. A. and Trueblood, K. N. IUCr World List of Crystallographic Computer Programs, 2nd Ed, Program 384 (1961).

7. Hudges, E. W. J. Amer. Chem. Soc. 63 (1941) 1737.

8. Freeman, A.J. Acta Crystallogr. 12 (1959) 261.

9. Stewart, R. F., Davidson, E. R. and Simpson, W. T. J. Chem. Phys. 42 (1965) 3175.

Received December 6, 1974. 